\title{
Phytochemical analysis, antimicrobial and radical-scavenging properties of Acalypha manniana leaves
}

\author{
Jaures AK Noumedem ${ }^{1}$, Jean de Dieu Tamokou ${ }^{1,3^{*}}$, Gerald Ngo Teke ${ }^{2}$, Rosine CD Momo ${ }^{1}$, Victor Kuete ${ }^{1}$ \\ and Jules Roger Kuiate ${ }^{1,3^{*}}$
}

\begin{abstract}
Acalypha manniana (Euphorbiaceae) is a plant popularly used in Cameroon and in several parts of Africa for the treatment of various microbial diseases like diarrhea and skin infections.

The present study was designed to evaluate the phytochemical composition, antimicrobial and radical-scavenging activities of $A$. manniana methanol leaf extract and its fractions.

The methanol extract was partitioned into hexane, ethyl acetate and residual fractions and phytochemical analysis was conducted using standard methods. The broth microdilution method was used to evaluate the antimicrobial activity against nine bacterial species and four dermatophyte species. The free radical scavenging activities of the methanol extract and its fractions were evaluated using the 2,2-diphenyl-1-picrylhydrazyl (DPPH) assay.

The results obtained showed that A. manniana contains alkaloids, tannins, anthocyanins, flavonoids, phenols and steroids. The methanol extract as well as the hexane, ethyl acetate and residual fractions exhibited both antibacterial and antidermatophytic activities that varied between the microbial species (MIC $=0.12-2.04 \mathrm{mg} / \mathrm{mL}$ ). These tested samples also showed high radical-scavenging activities ( $R a S_{50}=3.34-4.80 \mu \mathrm{g} / \mathrm{mL}$ ) when compared with vitamin $C$ used as reference antioxidant $\left(\mathrm{RaS}_{50}=1.74 \mu \mathrm{g} / \mathrm{mL}\right)$.

These findings provide evidence that the studied plant possesses antimicrobial and antioxidant properties and may act as potential antioxidant for biological systems susceptible to free radical-mediated reactions.
\end{abstract}

Keywords: Acalypha manniana; Euphorbiaceae; Extracts; Phytochemicals; Antimicrobials; Free radical scavenging

\section{Background}

The search for new antimicrobial and antioxidant agents from natural sources has intensified in response to the limitations of currently available therapy and the emergence of drug-resistant strains. Plants produce diverse range of bioactive molecules, making them a rich source of different types of potential drugs (Walton 1999; Ghasemzadeh et al. 2010; Jaiswal et al. 2010). Herbal drugs have gained importance in recent years because of their efficacy and cost effectiveness (Ripa et al. 2009). Today, nearly $88 \%$ of the global populations turn to plant derived

\footnotetext{
* Correspondence: jtamokou@yahoo.fr; jrkuiate@yahoo.com

${ }^{1}$ Department of Biochemistry, Faculty of science, University of Dschang, P.O.

Box 67, Dschang, Cameroon

${ }^{3}$ Laboratory of Microbiology and Antimicrobial Substances, Faculty of

Science, University of Dschang, P.O. Box 67, Dschang, Cameroon

Full list of author information is available at the end of the article
}

medicines as their first line of action for maintaining health and combating diseases (Govindarajan et al. 2008). According to the World Health Organization, medicinal plants would be the best source to obtain a variety of drugs (Nascimento et al. 2000). Thus, many plants that are of medicinal importance have been investigated by various researchers (Ali et al. 2000; Prasad et al. 2004; Kuete et al. 2008; Souza et al. 2008; Tenjoh et al. 2012). The success story of chemotherapy lies in the continuous search for new drugs to counter the challenge posed by resistant strains of microorganisms (Haruna et al. 2013). The investigation of certain indigenous plants for their antioxidant and antimicrobial properties may yield useful results. Cameroon has a great variety of natural vegetation, which is used in traditional medicine to cure various ailments. Among the plants used for medicinal purpose in Africa, particularly in Cameroon is Acalypha manniana.

\section{实 Springer}


Acalypha manniana Müll. Arg., belonging to the family of Euphobiaceae, is a slender climbing shrub that grows to about $6 \mathrm{~m}$ high in marshy places. According to some traditional healers found in the Western region of Cameroon, decoction of the leaves is used for the treatment of mycosis and skin diseases. A leafy stem decoction of A. manniana is taken in some African countries like Ivory Coast, Ghana, Uganda, Rwanda, Burundi and Cameroon to treat diarrhoea (Schmelzer 2007; Shmelzer et al. 2008). Previous studies have reported the presence of phenolics, tannins, alkaloids, steroids, flavonoids, glycosides and saponins in the leaf extracts of $A$. alnifolia (Evanjelene \& Natarajan 2012) and A. indica (Mohan et al. 2012). The ethanolic extract of $A$. wilkesiana leaves revealed the presence of tannins, steroids, flavonoids and cardiac glycosides while saponins, alkaloids and anthraquinones were not present (Gotep et al. 2010). A variety of phenolic compounds and fatty acids methyl ester were found in the A. monostachya extracts (Canales et al. 2011). The antifungal properties of extracts of leaves of A. hispida have been established (Ejechi \& Souzey 1999). Gallic acid, corilagin and geraniin have been reported to be the active compounds responsible for the antimicrobial activity of $A$. wilkesiana while quercetin 3-O-rutinoside and kaempferol 3-O-rutinoside were also isolated from the inactive fraction of $A$. hispida (Adesina et al. 2000). The antibacterial, antifungal and/or antioxidant activities of A. monostachya, A. wilkesiana, A. indica, A.alnifolia, A. hispida were also mentioned (Alade \& Irobi 1993; Canales et al. 2011; Shirwaikar et al. 2004; Govindarajan et al. 2008; Durga et al. 2009; Onocha et al. 2011; Evanjelene \& Natarajan 2012; Haruna et al. 2013). However, no systematic work has been undertaken on analyzing the extracts of $A$. manniana. In the continuation of the strategy of new drug discovery, we studied the phytochemical composition, antimicrobial and antioxidant activities of the A. manniana methanol leaf extract and its three derivative fractions.

\section{Materials and methods}

Plant material

The leaves of Acalypha manniana were collected in Dschang, West Region of Cameroon, in February 2009. Authentification of the plant was done at the Cameroon National Herbarium, where the voucher specimen was deposited under the accessory number 18223/SRF/CAM.

\section{Preparation of the methanol extract and its fractions}

The collected leaves were washed before being air-dried for three weeks. The dried leaves were ground into fine texture using an electric blender. The air-dried and powdered leaves $(1 \mathrm{Kg})$ were extracted by maceration in six liters of methanol for 72 hours at room temperature. Thereafter, it was filtered with Whatman paper number one and the methanol evaporated at $50^{\circ} \mathrm{C}$ under reduced pressure using a rotary evaporator (Buchi Rotavapor R-200). This yielded $212 \mathrm{~g}$ of concentrated extract. A portion of $60 \mathrm{~g}$ of methanol extract was successively partitioned with $n$-hexane and ethyl acetate to yield $5.54 \mathrm{~g}$ of hexane fraction, $3.70 \mathrm{~g}$ of ethyl acetate fraction, and $48.62 \mathrm{~g}$ of residual fraction. The methanol crude extract and its fractions were stored at $+4^{\circ} \mathrm{C}$ till usage for phytochemical and biological assays.

\section{Phytochemical screening}

Phytochemical analysis for antimicrobial and antioxidant compounds was done using standard methods described by (Bruneton 1999) for alkaloids, anthocyanins, flavonoids, phenols, triterpenes, steroids, saponins, tannins, anthraquinones and coumarins.

\section{Microorganisms and culture media}

The microorganisms used in this study consisted of two Gram-positive bacteria (Staphylococcus aureus ATCC25922, Enterococcus faecalis ATCC10541), three Gram-negative bacteria (Escherichia coli ATCC11775, Pseudomonas aeruginosa ATCC27853, Klebsiella pneumoniae ATCC1 3883) which are reference strains obtained from the American Type Culture Collection, and four clinical isolates (Proteus mirabilis, Salmonella paratyphi A, Salmonella paratyphi $B$, Shigella flexneri) kindly provided by the Pasteur Centre (Yaoundé-Cameroon). Three dermatophyte strains (Trichophyton mentagrophytes E1425, Trichophyton terrestre E1501, Microsporum gypseum E1420) were collected from "Ecole Nationale Vétérinaire d'Alford, France" and one clinical isolate (Trichophyton equinum) kindly provided by the Pasteur Centre (Yaoundé-Cameroon). The bacterial and dermatophyte strains were grown at $37^{\circ} \mathrm{C}$ and $28^{\circ} \mathrm{C}$ on nutrient agar (NA, Conda, Madrid, Spain) and Sabouraud Dextrose Agar (SDA, Conda) slants respectively (Tamokou et al. 2009).

\section{Preparation of microbial inoculum}

The inocula of bacteria were prepared from $24 \mathrm{~h}$ old broth cultures. The absorbance was read at $600 \mathrm{~nm}$ and adjusted with sterile physiological solution to match that of a $0.5 \mathrm{McF}$ arland standard solution. From the prepared microbial solutions, other dilutions with sterile physiological solution were prepared to give a final concentration of $10^{6}$ colony-forming units (CFU) per milliliter (Tamokou et al. 2012).

Conidia suspensions of dermatophyte species were prepared from 10 days old cultures respectively. The number of conidia was determined using a spectrophotometer and adjusted with sterile saline $(\mathrm{NaCl})$ solution (0.90\%) to an absorbance of 0.600 at $450 \mathrm{~nm}$ corresponding to a final concentration of about $1 \times 10^{5}$ spores $/ \mathrm{mL}$ (Venugopal \& Venugopal 1992). 


\section{Antimicrobial assay}

The minimum inhibitory concentrations (MICs), minimum bactericidal concentrations (MBC) and minimum fungicidal concentrations (MFCs) were determined as previously described (Tamokou et al. 2009; Fogue et al. 2012)

For every experiment, a sterility check (5\% aqueous DMSO and medium), negative control (5\% aqueous DMSO, medium and inoculum) and positive control (5\% aqueous DMSO, medium, inoculum and water-soluble antibiotics) were included. MICs were assessed visually after the corresponding incubation period and were taken as the lowest sample concentration at which there was no growth or virtually no growth. The assay was repeated thrice.

For the minimum microbicidal concentration (MMC) determination, $10 \mu \mathrm{L}$ aliquots from each well that showed no growth of microorganism were plated on MuellerHinton Agar or Sabouraud Dextrose Agar and incubated at $37^{\circ} \mathrm{C}$ for $24 \mathrm{~h}$ (bacteria) and at $28^{\circ} \mathrm{C}$ for 10 days (dermatophytes). The lowest concentration that yielded no growth after the sub-culturing was taken as the MBCs or MFCs. Gentamycin (for bacteria) and griseofulvin (for dermatophytes) were used as positive controls.

\section{Antioxidant assay}

The free radical scavenging activity of the crude extract and fractions was evaluated as described by Tamokou et al. (2012) with slight modifications. The test samples were prepared in methanol and $100 \mu \mathrm{L}$ of each sample added to $900 \mu \mathrm{L}$ of 2,2-diphenyl-1-picryl-hydrazyl-hydrate ( $20 \mathrm{mg} / \mathrm{L} \mathrm{DPPH}$ ) methanol solution, to give final concentrations of 50,100, 200, 400 and $800 \mu \mathrm{g} / \mathrm{mL}$. Lascorbic acid was used as a positive control and $1 \mathrm{~mL}$ of $20 \mathrm{mg} / \mathrm{L}$ DPPH methanol solution was used as negative control. The content of each preparation was mixed and incubated at room temperature in a dark cupboard. The absorbance was then monitored after $30 \mathrm{~min}$ and converted into percentage of scavenging activity:

$\%$ scavenging activity $=$

[(Absorbance of control-Absorbance of test sample)

/Absorbance of control] $* \mathbf{1 0 0}$
The experiments were carried out in triplicate and the percentages of DPPH scavenged by test samples were compared to that of L-ascorbic acid. These radical scavenging percentages were plotted against the logarithmic values of the concentrations and a linear regression curve was established in order to calculate the $\mathrm{RSa}_{50}$, which are the amounts of sample necessary to decrease by $50 \%$ the free radical DPPH.

\section{Statistical analysis}

Statistical analysis was carried out using Statistical Package for Social Science (SPSS, version 12.0). The experimental results were expressed as the mean \pm Standard Deviation (SD). Group comparisons were performed using One Way ANOVA followed by Waller-Duncan Post Hoc test. A p value of 0.05 was considered statistically significant.

\section{Results and discussion}

The result from the present investigation showed the presence of alkaloids, phenols, flavonoids, anthraquinones, anthocyanins, tannins and steroids in the A. manniana leaf extract (Table 1). These compounds varied within the fractions. In agreement with our results, the phytochemical screening of the leaf extracts of Acalypha hispida, A. marginata, A. racemosa, A. monostachya, A. alnifolia, A. wilkesiana and $A$. indica revealed the presence of phenolics, tannins, steroids, flavonoids, glycosides, saponins and anthraquinones that varied within the plant species (Iniaghe et al. 2009; Gotep et al. 2010; Canales et al. 2011; Evanjelene \& Natarajan 2012; Mohan et al. 2012).

The results in Table 2 show that the methanol extract and its fractions prevented the growth of all tested microorganisms, with MIC values ranging between 0.12 and $2.04 \mathrm{mg} / \mathrm{mL}$ for bacteria, and from 0.25 to $1.02 \mathrm{mg} / \mathrm{mL}$ for dermatophytes. S. flexneri, P. mirabilis and T. equinum $(\mathrm{MIC}=0.25-0.51 \mathrm{mg} / \mathrm{mL})$ were the most sensitive microorganisms while $S$. aureus $(\mathrm{MIC}=0.25-2.04 \mathrm{mg} / \mathrm{mL}$ ) was the most resistant. The lowest MIC value for these tested samples $(\mathrm{MIC}=0.12 \mathrm{mg} / \mathrm{mL})$ was obtained with ethyl acetate fraction on $P$. aeruginosa. The findings of the present

Table 1 Main groups of potential antimicrobial and antioxidant compounds found in the extracts of $A$. manniana

\begin{tabular}{|c|c|c|c|c|c|c|c|c|c|c|c|c|}
\hline & \multirow[t]{2}{*}{ Extraction Yield $(g / 100 g)$} & \multirow[t]{2}{*}{ Physical aspect } & \multicolumn{10}{|c|}{ Main groups of antimicrobial/antioxidant compounds } \\
\hline & & & Alca & Antho & Anthra & Couma & Flavo & Phen & Sapo & Ster & Tan & Triter \\
\hline Methanol extract & 11.50 & Dark green sticky & + & + & + & - & + & + & - & + & + & - \\
\hline Hexane fraction & 9.23 & Dark creamy & - & + & - & - & - & + & - & + & - & - \\
\hline Ethyl acetate fraction & 6.16 & Green streaky & + & + & - & - & + & + & - & + & + & - \\
\hline Residual fraction & 81.03 & Brown powdery & + & + & + & - & - & + & - & - & + & - \\
\hline
\end{tabular}

- : absent; + : present; Alca: alkaloids; Antho: anthocyanins; Anthra: anthraquinones; Couma: coumarins; Flavor: flavonoids; Phen: phenols; Sapo: saponins; Ster: steroids; Tan: tannins; Triter: triterpens. 
Table 2 Inhibition parameters (MIC, MBC) of methanol extract and its fractions from A. manniana leaves (mg/mL)

\begin{tabular}{|c|c|c|c|c|c|c|c|}
\hline & Microorganisms & Parameters & $\begin{array}{l}\text { Methanol } \\
\text { extract }\end{array}$ & $\begin{array}{l}\text { Hexane } \\
\text { fraction }\end{array}$ & $\begin{array}{l}\text { Ethyl acetate } \\
\text { fraction }\end{array}$ & $\begin{array}{l}\text { Residual } \\
\text { fraction }\end{array}$ & Ref* $^{*}$ \\
\hline \multirow[t]{24}{*}{ Bacteria } & Salmonella typhi & MIC & 0.25 & 2.04 & 0.51 & 0.25 & 0.032 \\
\hline & & MBC & 4.09 & 8.19 & 4.09 & 1.02 & 0.12 \\
\hline & & $\mathrm{MBC} / \mathrm{MIC}$ & 8 & 4 & 8 & 4 & 4 \\
\hline & Staphylococcus aureus & MIC & 0.25 & 2.04 & 0.51 & 2.04 & 0.002 \\
\hline & & MBC & 4.09 & 8.19 & 4.09 & 8.19 & 0.016 \\
\hline & & $\mathrm{MBC} / \mathrm{MIC}$ & 8 & 4 & 8 & 2 & 8 \\
\hline & Pseudomonas aeruginosa & MIC & 0.51 & 1.02 & 0.12 & 2.04 & 0.002 \\
\hline & & MBC & 2.04 & 4.09 & 2.04 & 4.09 & 0.016 \\
\hline & & $\mathrm{MBC} / \mathrm{MIC}$ & 4 & 4 & 8 & 2 & 8 \\
\hline & Escherichia coli & MIC & 0.51 & 1.02 & 0.51 & 0.25 & 0.016 \\
\hline & & MBC & 2.04 & 4.09 & 1.02 & 2.04 & 0.064 \\
\hline & & $\mathrm{MBC} / \mathrm{MIC}$ & 4 & 4 & 2 & 8 & 4 \\
\hline & Klebsiella pneumoniae & MIC & 0.51 & 1.02 & 0.51 & 0.51 & 0.008 \\
\hline & & MBC & 4.09 & 4.09 & 4.09 & 4.09 & 0.016 \\
\hline & & $\mathrm{MBC} / \mathrm{MIC}$ & 8 & 4 & 8 & 8 & 2 \\
\hline & Shigella flexneri & MIC & 0.25 & 0.51 & 0.51 & 0.51 & 0.002 \\
\hline & & MBC & 1.02 & 1.02 & 1.02 & 4.09 & 0.002 \\
\hline & & $\mathrm{MBC} / \mathrm{MIC}$ & 4 & 2 & 2 & 16 & 1 \\
\hline & Enterococcus faecalis & MIC & 0.25 & 1.02 & 0.51 & 1.02 & 0.001 \\
\hline & & MBC & 1.02 & 2.04 & 1.02 & 2.04 & 0.001 \\
\hline & & $\mathrm{MBC} / \mathrm{MIC}$ & 4 & 2 & 2 & 2 & 1 \\
\hline & Proteus mirabilis & MIC & 0.51 & 0.51 & 0.51 & 0.51 & 0.001 \\
\hline & & MBC & 0.51 & 2.04 & 1.02 & 4.09 & 0.001 \\
\hline & & $\mathrm{MBC} / \mathrm{MIC}$ & 1 & 4 & 2 & 8 & 1 \\
\hline \multirow[t]{4}{*}{ Dermatophytes } & $\begin{array}{l}\text { Trichophyton } \\
\text { mentagrophytes }\end{array}$ & MIC & 0.25 & 1.02 & 0.51 & 0.51 & 0.01 \\
\hline & T. equinum & MIC & 0.25 & 0.25 & 0.25 & 0.51 & 0.005 \\
\hline & T. terrestre & MIC & 0.51 & 0.51 & 0.25 & 1.02 & 0.005 \\
\hline & Microsporum gypseum & MIC & 0.25 & 0.25 & 0.51 & 1.02 & 0.01 \\
\hline
\end{tabular}

${ }^{*}$ Ref = reference drugs: gentamycin for bacteria and griseofulvin for dermatophytes.

study explain why the plant extracts are used in traditional folk medicine and confirm the activity of $A$. manniana as a broad spectrum antimicrobial agent since it inhibited the growth of Gram-positive (S. aureus, E. faecalis) and gram negative bacteria $(E$. coli, $P$. aeruginosa, $K$. pneumoniae, P. mirabilis, S. paratyphi A, S. paratyphi B, $S$. flexneri) as well as some fungi (T. mentagrophytes, $T$. terrestre, T. equinum, M. gypseum). Similar findings had been reported for other species by Canales et al. (2011) and Haruna et al. (2013). The antimicrobial activities of $A$. manniana ( $\mathrm{MIC}=0.25-2.04 \mathrm{mg} / \mathrm{mL}$ ) can also be considered very important compared with those of Haruna et al. (2013) who reported the antimicrobial activities of the leaves of A. wilkesiana methanolic extract and its four derivative fractions $(\mathrm{MIC}=25-100 \mathrm{mg} / \mathrm{mL}$ ) on human pathogenic bacteria namely S. aureus, S. pyogenes, E. faecalis, $P$. aeruginosa, P. vulgaris, E. coli, Aspergillus niger, A. flavus, A. carbonerium, T. mentagrophytes and Candida albicans. The fact that the methanolic extract of $A$. manniana and its fractions showed activity against most of the test microorganisms has added another plant in bank of herbal medicines.

Our data showed that the responses of microorganisms to tested substances varied in term of sensitivity among the strains. The differences in susceptibility may be explained by the differences in cell wall composition and/or in genetic content of plasmids that can be easily transferred among microbial strains (Karaman et al. 2003). It may also be explained by differences in the mechanism by which the active principles of the plant extracts exert 
their effect (Takeo et al. 2004). It was also observed that the ratios $\mathrm{MBC} / \mathrm{MIC}$ found for the tested substances were generally less than or equal to 4 (Table 2), on the corresponding microbial species, suggesting that the killing effects of the extract/fractions could be expected on most of the tested micro-organisms (Tene et al. 2008; Tamokou et al. 2009). This is very interesting in view of the perspective of new antibacterial discovery from this plant, when considering the medical importance of the tested microorganisms. Although the MIC values were ranging between 0.25 and $1.02 \mathrm{mg} / \mathrm{mL}$ for the dermatophytes, the methanol extract and fractions exerted fungistatic effects, suggesting the formation of resistance structure of dermatophytes at high concentrations (Georgopoulos \& Skylakakis 1986).

The results of the antioxidant activities of the methanol extract, hexane, ethyl acetate and residual fractions are presented in Table 3. It appeared that the methanol extract and its fractions displayed important radicalscavenging activities against DPPH $\left(\mathrm{RaS}_{50}=3.34-4.80\right.$ $\mu \mathrm{g} / \mathrm{mL}$ ) when compared with L-ascorbic acid used as reference antioxidant $\left(\mathrm{RaS}_{50}=1.74 \mu \mathrm{g} / \mathrm{mL}\right)$. These observations demonstrate that the tested samples are free radical inhibitors or scavengers acting possibly as primary antioxidants. This is very promising in the perspective of new antioxidant discovery from plant extracts. The antimicrobial activity was more concentrated in the methanol extract and contrarily, the antioxidant activity is more concentrated in the residual fraction. This suggests that $A$. manniana contains several antioxidant and/or antimicrobial principles with different polarities as shown by the phytochemical analysis. The residual fraction (Rsa50 $=3.34 \mu \mathrm{g} / \mathrm{mL}$ ) was more active than the methanol extract (Rsa50 $=4.51 \mu \mathrm{g} / \mathrm{mL}$ ) and hexane fractions (Rsa50 $=4.81 \mu \mathrm{g} / \mathrm{mL}$ ) indicating that the active principles might be more concentrated in residual fraction and more diluted in others tested samples. The free radical scavenging activities of $A$. manniana $\left(\mathrm{RSa}_{50}=\right.$ $3.34-4.80 \mu \mathrm{g} / \mathrm{mL}$ ) are highest compared with those of Evanjelene \& Natarajan (2012) who reported the percentages of scavenging of the aqueous (91.56\%), chloroform

Table 3 DPPH radical scavenging activity of the methanol extract and its fractions from Acalypha manniana leaves

\begin{tabular}{ll}
\hline Test substances & $\mathbf{R S a}_{\mathbf{5 0}}(\boldsymbol{\mu \mathbf { g }} \mathbf{\mathbf { m L } )}$ \\
\hline Methanol extract & $4.51 \pm 1.28^{\mathrm{c}}$ \\
Hexane fraction & $4.80 \pm 0.01^{\mathrm{c}}$ \\
Ethyl acetate fraction & $4.01 \pm 0.07^{\mathrm{bc}}$ \\
Residual fraction & $3.34 \pm 0.00^{\mathrm{b}}$ \\
L-ascorbic acid & $1.74 \pm 0.01^{\mathrm{a}}$ \\
\hline
\end{tabular}

$\mathrm{RSa}_{\mathbf{5 0}}$ : concentration of tested sample necessary to decrease by $50 \%$ the free radical DPPH. Values bearing the different superscript letters are significantly different $(p<0.05)$.
(52.55\%), petroleum ether (48.34\%) and methanol (88.76\%) extracts of A.alnifolia leaves on DPPH at $0.16 \mathrm{~mL}$ of extracts per milliliter of solution.

Many plant extracts exhibit efficient antioxidant properties due to their phytoconstituents, including phenolics and nitrogenous compounds (Durga et al. 2009; Evanjelene \& Natarajan 2012; Tatsimo et al. 2012; Tamokou et al. 2013), which were found to be present in our extracts. DPPH is a stable free radical at room temperature and accepts an electron or hydrogen radical to become stable diamagnetic molecules (Soares et al. 1997). Phenolics and nitrogenous compounds are known to be potential antioxidant due to their ability to scavenge free radicals through donation of hydrogen, forming the reduced form of DPPH. Therefore, the presence of such compounds may be responsible for the antioxidant activity found in the methanol extract and its fractions.

\section{Conclusions}

The methanol extract of A. manniana showed the highest antimicrobial activity while the residual fraction displayed the largest scavenging activity against DPPH confirming the traditional use of this plant in the treatment of various bacterial diseases such as diarrhea and skin infections. The residual fraction of $A$. manniana extract can be explored for its applications in the prevention of free radical related diseases. The obtained results might be considered sufficient for further studies geared towards the isolation and identification of the active principles and to evaluate possible synergistic effects among the extract components for their antimicrobial and radical-scavenging properties. Toxicity studies will be also necessary to establish if the crude extract/fractions could be safely used as antimicrobial/antioxidant agents.

\section{Competing interests}

The authors declare that they have no competing interests.

Authors' contributions

JAKN and RCDM designed the study, did the preparation of the extracts and the antimicrobial tests under the supervision of JRK. JDT did the phytochemical analysis and antioxidant assay. GNT and VK helped in the biological assays. JDT, GNT, VK and JRK wrote the manuscript. All authors read and approved the final manuscript.

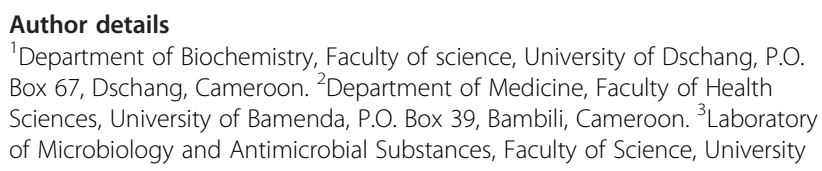




\section{References}

Adesina SKO, Idowu AO, Ogundaini H, Oladimeji TA, Olugbade GO, Onawunmi M (2000) Antimicrobial constituents of the leaves of Acalypha wilkesiana and Acalypha hispida. Phytother Res 14(5):371-374

Alade PI, Irobi ON (1993) Antimicrobial activities of crude leaf extracts of Acalypha wilkesiana. J Ethnopharmacol 39:171-174

Ali AM, Ismail NH, Yazan LS, Mohamed SM, Ho ASH, Lajis NH (2000) Antiviral, cytotoxic and antimicrobial activities of anthraquinones isolated from the roots of Morinda elliptica. Int J Pharm 4:298-301

Bruneton J (1999) Pharmacognosie, Phytochimie, Plantes Médicinales, 3èmeth edn. Lavoisier Tec et Doc, Paris, p 1120p

Canales M, Hernández T, Rodriguez-Monroy MA, Flores CM, Jiménez-Estrada M, Hernández LB, Durán A, Hernández-Moreno M, Trejo NA, Hernández AB (2011) Evaluation of the antimicrobial activity of Acalypha monostachya Cav. (Euphorbiales: Euphorbiaceae). Afr J Pharm Pharmacol 5(5):640-647

Durga RK, Karthikumar S, Jegatheesan K (2009) Isolation of potential antibacteria and antioxidant compounds from Acalypha indica and Ocimum basilicum. J Med Plants Res 3(10):703-706

Ejechi BO, Souzey JA (1999) Inhibition of biodeterioration of yam tuber Dioscorea rotundata Poir in storage with phenolic extract of Acalypha hispida Burm.f. leaves. J Stored Prod Res 35:127-134

Evanjelene KV, Natarajan D (2012) In Vitro Antioxidant and Phytochemical Analysis of Acalypha alnifolia Klein Ex Willd. IOSR J Pharm Biol Sci 1(5):43-47

Fogue PS, Lunga PK, Fondjo ES, Tamokou JD, Thaddée B, Tsemeugne J, Tchapi AT, Kuiate JR (2012) Substituted 2-aminothiophenes: antifungal activities and effect on Microsporum gypseum protein profile. Mycoses 55:310-317

Georgopoulos SG, Skylakakis G (1986) Genetic variability in the fungi and the problem of fungicide resistance. Crop Protect 5(5):299-305

Ghasemzadeh A, Jaafar HZE, Rahmat A (2010) Antioxidant activities, total phenolics and flavonoids Content in two varieties of malaysia young ginger (Zingiber officinale Roscoe). Molecules 15:4324-4333

Gotep JG, Agada GOA, Gbise DS, Chollom S (2010) Antibacterial activity of ethanolic extract of Acalypha wilkesiana leaves growing in Jos, Plateau State, Nigeria. Malaysian J Microbiol 6(2):69-74

Govindarajan M, Jebanesan A, Reetha D, Amsath R, Pushpanathan T, Samidurai K (2008) Antibacterial activity of Acalypha indica L. Eur Rev Med Pharm Sci 12:299-302

Haruna TM, Anokwuru PC, Akeredolu AA, Akinsemolu AA, Alabi OA (2013) Antibacterial and Antifungal Activity of Acalypha wilkesiana. Eur J Med Plants 3(1):52-64

Iniaghe OM, Malomo SO, Adebayo JO (2009) Proximate Composition and Phytochemical Constituents of Leaves of Some Acalypha Species. Pakistan J Nutr 8(3):256-258

Jaiswal YS, Tatke PA, Gabhe SY, VaidyA A (2010) Antioxidant Activity of Various Extracts of Leaves of Anacardium Occidentale. Res J Pharm Biol Chem Sci 1(4):112-119

Karaman I, Sahim F, Güllüce M, Ögütçü H, Sengul M, Adigüzel A (2003) Antimicrobial activity of aqueous and methanol extracts of Juniperus oxycedrus L. J Ethnopharmacol 85(2 \& 3):231-235

Kuete V, Mbaveng TA, Tsaffack M, Beng PV, Etoa FX, Nkengfack AE, Meyer M, Lall N (2008) Antitumor, antioxydant and antimicrobial activities of Bersama engleriana. J Ethnopharmacol 115:494-501

Mohan CS, Dinakar S, Anand T, Elayaraja R, SathiyaPriya B (2012) Phytochemical, GC-MS analysis and Antibacterial activity of a Medicinal Plant Acalypha indica. Int J Pharm Tech Res 4(3):1050-1054

Nascimento GGF, Lacatelli J, Freitas PC, Silva GL (2000) Antibacterial activity of plant extracts and phytochemicals on antibiotic-resistant bacteria. Braz $J$ Microbiol 31(4):886-891

Onocha PA, Oloyede GK, Afolabi QO (2011) Chemical composition, cytotoxicity and antioxidant activity of essential oils of Acalypha hispida flowers. Inter J Pharm 7(1):144-148

Prasad NR, Anandi C, Balasubramanian S, Pugalendi KV (2004) Antidermatophytic activity of extracts from Psoralea corylifolia (Fabaceae) correlated with the presence of a flavonoid compound. J Ethnopharmacol 91:21-24

Ripa FA, Haque M, Haque-UI-Imran (2009) In vitro antimicrobial, cytotoxic and antioxidant activity of flower extract of Saccharum spontanum Linn. Eur J Sci Res 30(3):478-483

Schmelzer GH (2007) Acalypha ornata Hochst. ex A.Rich. In: Schmelzer GH, Gurib-Fakim A (eds) Prota 11(1): Medicinal plants/Plantes médicinales 1. [CD-Rom]. PROTA, Wageningen, Netherlands
Schmelzer GH, Gurib-Fakim A, AGROOH (2008) Plantes Médicinales 1. Ressources végétales de l'Afrique tropicale 11 (1). Fondation PROTA, Wageningen, Pays, p Bas, Pp869

Shirwaikar A, Rajendran K, Bodla R, Kumar CD (2004) Neutralization potential of Viper russelli russelli (Russell's viper) venom by ethanol leaf extract of Acalypha indica. J Ethnopharmacol 94:267-273

Soares JR, Dinis TCP, Cunha AP, Almeida LM (1997) Antioxidant activities of some extracts of Thymus zygi. Free Rad Res 26:469-478

Souza RSO, Albuquerque UP, Monteiro JM, Amorin ELC (2008) Jurema-preta (Mimosa tenuiflora [wild.] poir) a review of its traditional use, phytochemistry and pharmacology. Braz Arch Biol Techn 51(5):937-947

Takeo O, Masato K, Keiko S, Rika O, Junko M, Hiroshi I, Hiroyuki K, Toshi A, Toshifumi A, Shigeo M (2004) In Vitro and in vivo Antibacterial Activities of the Tricyclic Ketolide Te-802 and its Analogs. J Antibiot 57:518-527

Tamokou JD, Tala FM, Wabo KH, Kuiate JR, Tane P (2009) Antimicrobial Activities of Methanol Extract and Compounds from Stem Bark of Vismia rubescens. J Ethnopharmacol 124:571-575

Tamokou JD, Mpetga Simo DJ, Lunga PK, Tene M, Tane P, Kuiate JR (2012) Antioxidant and Antimicrobial Activities of Ethyl Acetate Extract, Fractions and Compounds from the Stem Bark of Albizia adianthifolia (Mimosoideae). BMC Compl Altern Med 12:99

Tamokou JD, Chouna JR, Fischer-Fodor E, Chereches G, Barbos O, Damian G, Benedec D, Duma M, Nkeng Efouet AP, Wabo KH, Kuiate JR, Mot A, Dumitrescu SR (2013) Anticancer and antimicrobial activities of some antioxidant-rich Cameroonian medicinal plants. PLoS One 8(2):e0055880

Tatsimo NSJ, Tamokou JD, Havyarimana L, Dezső C, Forgo P, Hohmann J, Kuiate $J R$, Tane P (2012) Antimicrobial and antioxidant activity of kaempferol rhamnoside derivatives from Bryophyllum pinnatum. BMC Res Notes 5:158

Tene M, Tane P, Tamokou JD, Kuiate JR, Connolly JD (2008) Degraded diterpenoids from the stem bark of Neoboutonia mannii. Phytochem Lett 1:120-124

Tenjoh TR, Tamokou JD, Chekem GMS, Kuiate JR (2012) Antibacterial activity of ethanol crude extract and fractions of Piptadeniastrum africanum (Mimosaceae). Novus Nat Sci Res 1(4):19-30

Venugopal PV, Venugopal TV (1992) In vitro susceptibility of dermatophytes to imidazoles. Indian J Dermatol 37:35-41

Walton NJ, Brown DE (1999) Chemicals from Plants: Perspectives on Plant Secondary Products. Imperial College press, London, UK

\section{doi:10.1186/2193-1801-2-503}

Cite this article as: Noumedem et al:: Phytochemical analysis, antimicrobial and radical-scavenging properties of Acalypha manniana leaves. SpringerPlus 2013 2:503.

\section{Submit your manuscript to a SpringerOpen ${ }^{\circ}$ journal and benefit from:}

- Convenient online submission

- Rigorous peer review

- Immediate publication on acceptance

- Open access: articles freely available online

- High visibility within the field

- Retaining the copyright to your article

Submit your next manuscript at $\boldsymbol{\wedge}$ springeropen.com 